\title{
The effects of transnational parenting on the subjective health and well-being of Ghanaian migrants in The Netherlands
}

Citation for published version (APA):

Dito, B. B., Mazzucato, V., \& Schans, D. (2017). The effects of transnational parenting on the subjective health and well-being of Ghanaian migrants in The Netherlands. Population Space and Place, 23(3), e2006. [2006]. https://doi.org/10.1002/psp.2006

Document status and date:

Published: 01/04/2017

DOI:

10.1002/psp.2006

Document Version:

Publisher's PDF, also known as Version of record

Document license:

Taverne

Please check the document version of this publication:

- A submitted manuscript is the version of the article upon submission and before peer-review. There can be important differences between the submitted version and the official published version of record.

People interested in the research are advised to contact the author for the final version of the publication, or visit the DOI to the publisher's website.

- The final author version and the galley proof are versions of the publication after peer review.

- The final published version features the final layout of the paper including the volume, issue and page numbers.

Link to publication

\footnotetext{
General rights rights.

- You may freely distribute the URL identifying the publication in the public portal. please follow below link for the End User Agreement:

www.umlib.nl/taverne-license

Take down policy

If you believe that this document breaches copyright please contact us at:

repository@maastrichtuniversity.nl

providing details and we will investigate your claim.
}

Copyright and moral rights for the publications made accessible in the public portal are retained by the authors and/or other copyright owners and it is a condition of accessing publications that users recognise and abide by the legal requirements associated with these

- Users may download and print one copy of any publication from the public portal for the purpose of private study or research.

- You may not further distribute the material or use it for any profit-making activity or commercial gain

If the publication is distributed under the terms of Article $25 \mathrm{fa}$ of the Dutch Copyright Act, indicated by the "Taverne" license above, 


\title{
The Effects of Transnational Parenting on the Subjective Health and Well-Being of Ghanaian Migrants in the Netherlands
}

\author{
Bilisuma B. Dito ${ }^{1, *}$, Valentina Mazzucato ${ }^{1}$ and Djamila Schans ${ }^{2}$ \\ ${ }^{1}$ Department of Technology and Society Studies, Maastricht University, Maastricht, the Netherlands \\ ${ }^{2}$ Research and Documentation Center, Ministry of Security and Justice, the Hague, the Netherlands
}

\section{ABSTRACT}

Migrant parents from the Global South who migrate to the Global North often leave their children in the origin country either by choice or as a result of stringent migration policies in migrant-receiving countries that make family migration impracticable. Small-scale, qualitative studies have indicated that these transnational parents experience emotional and health difficulties due to separation. Few studies have investigated these effects on a larger scale using quantitative data, and no previous studies compared their findings with a control group. The current paper used a survey that was conducted with 303 Ghanaian migrant parents living in the Netherlands to examine the effects of transnational family life on self-reported health and subjective well-being (as measured through satisfaction with life and emotional well-being). The study shows that migrant parents who are separated from their children display worse outcomes than their counterparts who live with their children in the destination country. Importantly, however, these differences were mediated by these parents' lower socioeconomic and undocumented status. Copyright (c) 2016 John Wiley \& Sons, Ltd.

\section{Accepted 30 October 2015}

Keywords: the Netherlands; transnational parenting; international migration; health status; subjective well-being; Ghana

*Correspondence to: Bilisuma B. Dito, Department of Technology and Society Studies, Maastricht University, Maastricht, the Netherlands.

E-mail: bilisuma.dito@maastrichtuniversity.nl

\section{INTRODUCTION}

$\mathrm{M}$ any parents move overseas to earn a living, in part, to ensure a better future for their children. These parents often migrate and leave their children in the home country in the care of another family member while also participating in raising their children across international borders. An important empirical concern is whether such arrangements have negative impacts on the parents' well-being.

In the past, studies on migration and development mainly focused on remittances and their effects on poverty alleviation for households in the migrants' home countries, often ignoring the differential effects of migration on different family members (Mazzucato \& Schans, 2011). Studies, instead, focusing on migrant well-being in receiving countries have indicated that migrants experience negative well-being (Noh \& Avison, 1996; Dunn \& Dyke, 2000; Griffin \& Soskolne, 2003). However, they explain this finding in relation to the migrants' lives in the receiving country without consideration of the potential implications of transnational relationships.

Recently, quantitative studies have examined the effects of transnational relationships on families, focusing mainly on the left-behind children (Giannelli \& Mangiavacchi, 2010; McKenzie \& Rapoport, 2011; Bennet et al., 2014). Some qualitative transnational family studies have focused on migrant parents and emphasised the negative effects of separation on parents' well-being (Parreñas, 2005; Dreby, 2007; Bernhard et al., 2008; Fresnoza-Flot, 2009). However, these studies rely on few cases and do not compare the study group with a control group. Therefore, it is unclear whether the effects on transnational parents are due to living separately from their children or to other conditions. Furthermore, 
most of these previous studies are based on cases from Latin America and Asia, leaving a gap in knowledge about migrant parents from Africa.

The current study examines the consequences of family separations due to international migration on the well-being of Ghanaian migrant parents in the Netherlands. It focuses on three outcomes, self-reported health status, satisfaction with life, and emotional well-being, to capture various aspects of migrants' well-being. Ghanaian migrants are chosen because they are the largest migrant group from sub-Saharan Africa living in the Netherlands, who are not refugees. Furthermore, most work on migrants in the Netherlands has focused on older migrant groups such as guest workers from Morocco and Turkey who faced very different economic and legal circumstances than the new migrant groups entering since the 1980s (Mazzucato, 2008). We expect therefore that they will show different dynamics than older migrant groups.

This study contributes to the literature on migration and well-being in three ways. First, the current study is one of the first to quantitatively investigate transnational families by including a control group of migrant parents who live with their children in the migrant-receiving country. This method allows us to understand the unique situation of transnational parents. Second, the study adds the examination of transnational family structures to the migrant well-being literature, which has primarily focused on migrant families in which all members are located in the migrant-receiving countries. Third, the focus on an African case may present dynamics that differ from those that have been found for migrants who originated from other parts of the world. African family systems are viewed as flexible because of their norms of social parenthood and child fostering (Oppong, 1973; Bledsoe \& IsingoAbanike, 1989). These norms could lead to different consequences of transnational parents' well-being. Specifically, we expect it to be more socially acceptable for a parent to ask a caregiver to care for one's children in the African context than in parts of the world where these norms are not as prevalent.

\section{THEORETICAL CONSIDERATIONS}

Two bodies of literature examine the links between international migration and migrants'

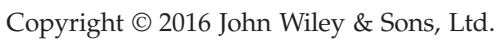

well-being status. The migrant well-being literature uses predominantly quantitative methods and focuses on how migrants fare in the destination country. By contrast, transnational family studies are typically small-scale case studies that focus on family relationships across nation-state borders.

The migrant well-being literature compares migrants with the native population (Chen et al., 1996; Dunn \& Dyke, 2000; Friesbie et al., 2001; Zhang et al., 2010) or migrants within an immigrant population (Beiser et al., 1995; Noh \& Avison, 1996; Griffin \& Soskolne, 2003; Sharareh et al., 2007). In these studies, outcomes that are related to self-reported health status, emotional health, and healthcare utilisation improve with better education and economic status (Hao \& Johnson, 2000; Sharareh et al., 2007; Leu et al., 2008), better social support within and outside of one's own community (Noh \& Avison, 1996; Griffin \& Soskolne, 2003; Oppedal et al., 2004; Jasinskaja et al., 2006), longer duration of stay (Dias et al., 2008; Lebrun, 2008), and documented status (Berk et al., 2000; Knipscheer et al., 2000; Cavazos-Rehg et al., 2007; Dias et al., 2008).

Some of these studies have considered family characteristics such as family size (Frisbie et al., 2001), marital status or whether the migrant lives with a spouse (Frisbie et al., 2001; Cavazos-Rehg et al., 2007), and whether the migrant has children (Hao \& Johnson, 2000). However, none of the studies have distinguished where the spouse or the children live or have included characteristics of the nuclear family members who are located in a different country. This missing information reflects an implicit assumption in the family studies literature that geographic proximity is necessary for meaningful interactions and exchanges within families and households, leaving that which is not geographically proximate outside of the purview of research (Mazzucato \& Schans, 2011).

Yet, transnational relationships are an important component of migrants' lives. The qualitative transnational family literature highlights that migrants' well-being is related to their ties with their family members in their countries of origin. The findings from these studies have indicated that separation from one's child due to migration is associated with feelings of depression, hopelessness, guilt, inability to function, and loss of meaning of life among migrant parents (Schmalzbauer, 
2004; Parreñas, 2005). These effects are especially evident in mothers because of the strong gender ideologies in the countries of origin (the Philippines and Latin America in these cases). Transnational family studies have documented the difficulties that migrant mothers face in balancing the economic benefits of migration and the emotional cost of losing contact with their children (Parreñas, 2001; Zontini, 2004; Parreñas, 2005; Dreby, 2006; Viruell-Fuentes, 2006; Fresnoza-Flot, 2009; Horton, 2009; Moran-Taylor, 2008). Children in the home country detach themselves from their parents because of anger and feelings of abandonment. This leads to parents' further distress (Parreñas, 2005; Dreby, 2007). An additional component to parents' low levels of well-being is the social stigma in some origin countries attached to leaving one's children behind and the ensuing feelings of guilt and shame that parents experience (Parreñas, 2005; Bernhard et al., 2008). Furthermore, parents may experience distress when they feel that their children at home are not being properly raised (Tizard, 1991; Mazzucato \& Schans, 2011).

In general, transnational family studies adopt a qualitative analytical approach that primarily focuses on the experiences of female migrants. Differences between the experiences of people of different sex, socio-economic status, documented status, and the characteristics of their children in the countries of origin are seldom explicitly analysed. Yet, these factors may be important in determining how parents experience the separation from their child. For example, some studies have argued that undocumented status lengthens the separation, limits parenting to only sending remittances and making phone calls, and results in a weak parent-child relationship (FresnozaFlot, 2009; Horton, 2009). However, these findings are open to further investigation because these studies have not compared undocumented parents with documented parents. At the same time, the migrant well-being literature ignores the implications of transnational relationships on the well-being of migrants because it only focuses on factors that are related to the migrants' lives in the destination country. The current study adds the findings of transnational family studies to the study of migrant well-being by analysing the relationship between transnational family constellations and migrant parents' well-being conditional on the migrants' characteristics.
The main hypothesis, derived from the qualitative transnational family literature, is that Ghanaian transnational parents have lower levels of wellbeing compared with Ghanaian migrant parents who live with their children in the destination country. Yet, a second hypothesis, derived from the migrant well-being literature, is that this difference in well-being between the two groups of parents is related to parents' socio-demographic, socio-economic, social network, and migration characteristics.

We further investigate whether transnational parents exhibit differential effects of living transnationally. To our knowledge, no study has examined this question; therefore, we cannot base our hypotheses on the literature. However, there are two characteristics, one that relates to the Ghanaian context and one that relates to the Dutch context, that allow us to formulate a hypothesis. Transnational family arrangements may be a preferred option for parents, at least in the short run, because it helps them to reap the most economic benefits while abroad without engaging in child care.

Some Ghanaian parents living in the US and the Netherlands expressed a preference for the Ghanaian school system, especially when parents live in low-income neighbourhoods with difficult access to good schools and the stricter disciplining norms in Ghana (Bledsoe \& Sow, 2011; Coe, 2008; Poeze \& Mazzucato, 2012). The laxity of child-raising norms in the West is perceived as limiting parents' ability to discipline their children through measures, such as physical punishment, that are deemed important. As a result of these, children who spend their formative years in Europe and North America are considered more likely to leave school early, join gangs, and be uncontrolled and confrontational (Bledsoe \& Sow, 2011). Additionally, temporary separation may not be accompanied by parents' feelings of guilt or low well-being because social parenthood and child fostering, in which child raising is entrusted to others, are widely practised in Ghana irrespective of migration (Oppong, 1973; Bledsoe \& Isingo-Abanike, 1989).

At the same time, parent-child separation may be involuntary because of restrictive migration policies. The requirements for legal entry and family reunification have been raised in the past two decades in the Netherlands, lengthening the time of separation between parents and their 
children (Van Walsum, 2003). It is especially difficult for poor or undocumented migrants to visit their children because of the expenses of travel and the difficulties in obtaining a short-term visa for the child or a re-entry permit for the parent (Mazzucato, 2012). These conditions lead to our third hypothesis: there is a difference in the effect of living transnationally between parents for whom the situation is a choice and those who feel that it is a coerced situation due to destination country policies.

\section{GHANAIAN MIGRANTS IN THE NETHERLANDS}

In 2013, Ghana's population numbered 25.6 million (World Bank, 2015). While exact figures do not exist, estimate suggests that there were a total of 1.5 million Ghanaian migrants in 2003 (Twum Baah, 2005). Many of these migrants are located in the West African region, while in the West, the most common destinations are the UK, the US, Germany, Italy, Canada, and the Netherlands (Quartey, 2009; Schans et al., 2013).

Ghanaians started migrating to the Netherlands especially since the 1980 s as a result of the economic turmoil that Ghana experienced during the 1980s and the large-scale expulsion of Ghanaian labourers from Nigeria in that period (Peil, 2009). The Netherlands was an attractive destination because of its relatively open visa policy at the time (Schans et al., 2013). However, this was immediately followed by a time of an increasingly stringent migration regime. In the Netherlands, throughout the 1990s and 2000s, at the height of Ghanaian migration to the country, residency visas became more difficult to obtain and expensive (Mazzucato, 2008), and requirements for family reunification stricter. This different context of migration than earlier migration waves, such as those of the guest workers from Turkey and Morocco, has consequences for transnational family dynamics that warrant specific study (Grillo \& Mazzucato, 2008).

There were close to 22,263 officially registered Ghanaians including first-generation $(61 \%)$ and second-generation (40\%) Ghanaians in 2013 (Central Bureau of Statistics, 2014). The unregistered population is sizeable, estimated in 2000 to be the same size as the registered population, based on the number of Ghanaians residing in the Netherlands who registered to vote for
Ghana's presidential elections at the time (Mazzucato, 2008). Most are economic migrants, below 60 years of age $(97 \%)$, with almost equal numbers of men and women. A majority are Akan, and they are mainly (60\%) located in Amsterdam South East (Van Huis et al., 2004). Transnational family forms are prevalent among Ghanaian migrants as indicated by qualitative studies (Manuh, 1999; Mazzucato, 2008; Wong, 2014) and supported by localised surveys in Ghana (Caarls et al., 2013). We also know that in high-outmigration regions of Ghana, 16\% of secondary-school children had at least one parent on international migration in 2011 (Mazzucato et al., 2014). Regardless of this widespread phenomenon, quantitative analyses on the phenomenon and consequences for the different transnational family members are currently lacking.

\section{METHODOLOGY}

A survey of Ghanaian migrant parents in the Netherlands was conducted in 2011. Three hundred three Ghanaian migrant parents were interviewed who had at least one child below the age of 21, had spent at least one full year in the Netherlands, and had settled in the Netherlands for the first time as an adult (at age 18 and over). One parent per family was interviewed. The survey was conducted in the cities of Amsterdam, Almere, and The Hague, where most Ghanaians live.

No baseline survey of Ghanaians in the Netherlands exists; therefore, it was not possible to sample randomly. As a result, respondents were recruited through different gateways to ensure variability in the sample. Thirty-two per cent of respondents were selected through snowballing, $32 \%$ through personal contacts of the interviewers, and $16 \%$ through religious organisations such as churches and mosques; and 19\% were recruited in public places such as markets and shops. The interviewers were both male and female of different ages. They were expressly chosen from within and outside of the research population so that recruitment through their personal networks would lead to diversity in respondents. The interviews were conducted in English, Ghana's official language, as all respondents could express themselves in the language. A stratified sampling strategy was used to include a nearly equal number of parents who had at least one child in Ghana (55\%) and a 
control group of parents who lived with all of their children in the Netherlands (45\%). Quota sampling was employed for education and gender, resulting in the sample constituting 54\% fathers and $46 \%$ mothers, reflecting the ratios that were found in the documented Ghanaian population in the Netherlands (CBS, 2015). The majority of the sample (74\%) comes from the Akan ethnic group, in line with the migration patterns of ethnic groups from Ghana (Ghana Statistical Service, 2010).

\section{Dependent Variables}

Well-being was measured through self-reported health status and subjective well-being measures (life satisfaction and emotional well-being). Selfreported health status has been found to have good construct and criterion validity; it indicates individual health by predicting morbidity, mortality, and disability in later life and over a long term (Idler \& Benyamin, 1997; Idler \& Kasl, 1995; Diener, 1994).

The self-reported health is measured by asking respondents, 'On a scale from 1 to 5 , how do you rate your own health?' The possible responses range from 1, 'not good', to 5, 'very good'. The second and third dependent variables reflect subjective well-being as measured by satisfaction with life and emotional well-being. For satisfaction with life, participants responded to the following question: 'How do you rate your satisfaction with your life?' on a scale from (1)= 'not satisfied' to (5) = 'very satisfied'.

Emotional well-being was measured using the General Health Questionnaire (GHQ-12), which was developed by Goldberg (1978). This questionnaire's validity to measure emotional wellbeing has been shown in various cultural settings (Donath, 2001; Jackson, 2007; Montazeri et al., 2003; Schmitz et al., 1999). The survey asks 12 questions on symptoms of anxiety and psychological distress. Each question is scored on a 4point scale with the following responses: 'more than usual', 'the same as usual', 'less than usual', and 'much less than usual'. The responses were collapsed into two categories, indicating those who answered more or the same as usual and those who answered less or much less than usual. The measure was found to have good reliability $(\alpha=0.89)$, and a factor analysis showed that the 12 items measure a one-dimensional outcome. Thus, an emotional well-being outcome was constructed by adding the 12 general health questions, following Goldberg's original scoring method (Goldberg 1978). The aggregate outcome ranges from 0 to 12 . An increase in scores indicates worsening emotional well-being.

\section{Independent Variables}

Transnational parent status, the main variable of interest, was defined as a parent who had at least one child in Ghana at the time of the survey. A non-transnational parent was defined as a parent who lived with all of his or her children in the Netherlands. Lower levels of health and satisfaction with life were denoted by a significant and negative coefficient of the transnational parent variable, whereas lower levels of emotional well-being were denoted by a significant and positive coefficient.

This study controlled for the following demographic variables: sex $(0=$ female, $1=$ male); age in years; marital status $(0=$ single/divorced/ widowed, $1=$ married or in a relationship); educational status, consisting of 11 levels (1 indicating primary education and 11 indicating completion of university education); and socioeconomic status, consisting of wealth status in the destination country $(1=$ migrant owns a house in the Netherlands, $0=$ otherwise) and in the country of origin (number of assets in Ghana). The study also controlled for social networks, measured as the number of friends and family members that a migrant parent has in the host country. Furthermore, the migration-related variables of documented status $(1=$ documented, $0=$ undocumented) and length of stay in the Netherlands (in years) were controlled.

In a second part of the analysis, we examined heterogeneity within the transnational parent group. Four additional control variables that have not been considered in the transnational family literature were included. In line with the hypothesis in the previous section, the health and well-being of transnational parents could vary depending on whether separation from one's child is a preference. Parental preference was measured by asking respondents 'Would you like to live with your children?' The health and subjective well-being of transnational parents may also be sensitive to whether the parent has ever begun a reunification process, which might help the parent to feel that he or she is 
acting to change the current transnational situation. Moreover, the caregiver status (i.e. whether the other parent is the caregiver) is important, in line with Nobles' (2011) findings about Mexican migrant fathers' experience of better relationships with their children when the caregiver is the mother. Our study also included a variable that indicated whether the children in the country of origin are young (measured by the number of children in Ghana below the age of 11), in line with evidence showing young children's greater degree of emotional distress due to parental migration (Fan et al., 2012). We expect children's emotional distress to affect parents' distress.

\section{RESULTS}

A bivariate analysis was conducted to examine statistically significant differences between transnational parents and the control group of nontransnational parents in the outcomes and the control variables (Table 1). An independentsample $t$-test and a non-parametric Wilcoxon rank-sum (Mann-Whitney) test were used.

Multivariate analysis was composed of two steps. In the first step, we examined differences between transnational and non-transnational parents with respect to their health and two subjective well-being outcomes (Tables 2-4) while controlling for socio-demographic, socio-economic, social network, and migration characteristics. Sets of variables were entered in a stepwise fashion to examine any potential mediating factors. The first model included the variable of interest, the parent's transnational status. Subsequent models added the socio-demographic, socio-economic, social network, and migration status variables. The final two models included interaction effects of transnational parent status and socio-economic status in the Netherlands and documented status, as these two aspects condition how well migrants manage their transnational parenting.

In the second step, we analysed differences within the transnational parent group (Table 5). In both types of analysis, ordinary linear squares regression models were employed. We treated the outcome variables that were expressed in ordinal scales as continuous variables because of the small sample size. This study used cross-sectional data. Therefore, we do not claim causality; rather, we interpret the results as statistical associations.
Table 1 presents the summary statistics on the health and the well-being outcomes for the whole sample and separately for transnational and nontransnational parents. Overall, the interviewed parents reported high health status and wellbeing levels. They assessed their health and life satisfaction with an average score of 4 on a 5point scale and their emotional well-being with an average GHQ score of 2 on a 12-point scale.

In line with our hypothesis, the transnational parents reported worse health and well-being than the non-transnational parents. The bivariate analysis showed that these differences were statistically significant, with stronger statistical differences found for emotional well-being and satisfaction with life.

The two groups of parents also significantly differed in sex, age, socio-economic status, documented status, and duration of stay in the Netherlands. The transnational parents were predominantly male $(67 \%)$, were poorer (with only $15 \%$ reporting house ownership in the Netherlands in comparison with half in the non-transnational group), were mainly undocumented (32\% as compared with $98 \%$ for the non-transnational parents), and resided in the Netherlands for a shorter period of time, on average (8years as compared with 14 years for the non-transnational parents).

\section{Transnational Parents and Self-Reported Health Status}

We further investigated these associations for self-assessed health status using multivariate regression (Table 2). In Model 1, similar to the bivariate analysis reported previously, a negative and statistically significant relationship $(p=0.01)$ between being a transnational parent and the health status of Ghanaian migrant parents was found. The transnational parent variable remained significant after controlling for demographic characteristics and education (Model 2).

However, in Model 3, the transnational parent variable became insignificant when socio-economic status was considered, specifically when measured using house ownership in the Netherlands, which significantly increased self-reported health status by 34 percentage points $(p=0.01)$. The fact that the significance of the transnational parent variables disappeared in this model suggests that differences in self-reported health status between transnational 
Table 1. Characteristics of transnational parents and non-transnational parents.

\begin{tabular}{|c|c|c|c|c|}
\hline & Whole sample & Non-TN parent & TN parent & $p$-value \\
\hline \multicolumn{5}{|l|}{ Health and subjective well-being outcomes } \\
\hline Self-assessed health status & $4.19(0.78)$ & $4.28(0.72)$ & $4.11(0.82)$ & $0.07^{+}$ \\
\hline Satisfaction with life & $3.94(0.90)$ & $4.10(0.95)$ & $3.82(0.81)$ & $0.01^{*}$ \\
\hline Emotional well-being (GHQ-12) & $1.87(2.87)$ & $1,21(2.33)$ & $2.82(3.14)$ & $0.00^{* * *}$ \\
\hline \multicolumn{5}{|l|}{ Socio-demographic characteristics } \\
\hline Sex of the parent $(1=$ male $)(\%)$ & 54.52 & 38.41 & 67.06 & $0.00^{* * *}$ \\
\hline Age of the parent in years & $40.62(7.53)$ & $39.63(7.77)$ & $41.37(7.27)$ & $0.04^{*}$ \\
\hline $\begin{array}{l}\text { Marital status of the parent }(1=\text { married } / \\
\text { in a relationship })(\%)\end{array}$ & 80.65 & 81.16 & 81.18 & 0.99 \\
\hline Education status of the parent in levels & $7.82(2.36)$ & $7.83(2.34)$ & $7.81(2.39)$ & 0.94 \\
\hline \multicolumn{5}{|l|}{ Socio-economic status } \\
\hline Owns house in the Netherlands (1=yes) $(\%)$ & 30.00 & 48.55 & 15.29 & $0.00^{* * *}$ \\
\hline Number of assets owned in Ghana & $1.33(2.83)$ & $1.38(3.64)$ & $1.30(1.98)$ & 0.81 \\
\hline \multicolumn{5}{|l|}{ Social network variable } \\
\hline Number of family and friends in the Netherlands & $7.61(13.84)$ & $8.67(15.89)$ & $6.82(11.99)$ & 0.24 \\
\hline \multicolumn{5}{|l|}{ Migration variables } \\
\hline Documented status $(1=$ documented $)(\%)$ & 80.97 & 97.83 & 67.65 & $0.00^{* * *}$ \\
\hline Number of years in the Netherlands & $10.55(7.11)$ & $13.69(7.13)$ & $7.94(5.90)$ & $0.00^{* * *}$ \\
\hline Prefers to live with child $(1=$ yes $)(\%)$ & & & 77.33 & \\
\hline Ever started a procedure to bring child to the & & & 16.56 & \\
\hline Netherlands $(1=$ yes $)(\%)$ & & & & \\
\hline Caregiver is the other biological parent $(1=$ yes $)(\%)$ & & & 49.03 & \\
\hline Number of children in Ghana below 11 years & & & $1.79(0.85)$ & \\
\hline$N$ & 310 & 138 & 170 & \\
\hline
\end{tabular}

Source: Data on Transnational Child Raising Arrangements between Ghana and the Netherlands (TCRA), 2011.

Standard deviations are reported in parenthesis. $p$-values indicate statistical significance in the differences between transnational (TN) and nontransnational (non-TN) parents.

GHQ-12, General Health Questionnaire-12.

*** $p<0.001$;

${ }^{* *} p<0.01$

${ }^{*} p<0.05$;

${ }^{+} p<0.1$.

parents and the control group were substantially mediated by differences in their socio-economic status in the destination country.

In Model 4, we included social network and migration control variables. The socio-economic status, measured as house ownership in the Netherlands, and documented status were significant. The sex of the migrant parent was statistically significant $(p=0.10)$, although weak, when we included the socio-economic status, social network, and migration variables separately and simultaneously. Men's self-reported health status scores were 18 percentage points higher than those of women.

Models 5 and 6 included two interaction effects: being a transnational parent with high socio-economic status in the Netherlands and with documented status. The self-reported health status scores of transnational parents with better socio-economic status in the Netherlands were significantly higher than those of the same parents with lower socio-economic status (49 percentage points). No significant interaction effect of being a transnational parent and having documented status was found.

\section{Transnational Parents and Subjective Well-Being}

Tables 3 and 4 report results for the two subjective well-being indicators: satisfaction with life and emotional well-being. The results of Model 1 showed similar statistically significant effects of being a transnational parent as found in the case of self-reported health status. In Model 2, the effects on both outcomes remained after adjusting for socio-demographic characteristics, with slightly greater magnitudes of the transnational parent 
Table 2. Multivariate regressions of self-assessed health status: transnational versus non-transnational parents.

\begin{tabular}{|c|c|c|c|c|c|c|}
\hline & Model 1 & Model 2 & Model 3 & Model 4 & Model 5 & Model 6 \\
\hline Transnational parent $(1=$ yes $)$ & $-0.16^{+}(0.09)$ & $-0.20 *(0.09)$ & $-0.08(0.09)$ & $0.08(0.11)$ & $-0.05(0.12)$ & $-0.27(0.41)$ \\
\hline \multicolumn{7}{|l|}{ Socio-demographic characteristics } \\
\hline Sex $(1=$ male $)$ & & $0.11(0.10)$ & $0.12(0.10)$ & $0.18^{+}(0.10)$ & $0.17^{+}(0.10)$ & $0.18^{+}(0.10)$ \\
\hline Age (years) & & $-0.00(0.01)$ & $-0.00(0.010)$ & $-0.01(0.010)$ & $-0.01(0.01)$ & $-0.01(0.01)$ \\
\hline $\begin{array}{l}\text { Marital status }(1=\text { married } / \text { in a } \\
\text { relationship) }\end{array}$ & & $0.16(0.13)$ & $0.11(0.13)$ & $0.13(0.13)$ & $0.14(0.13)$ & $0.14(0.13)$ \\
\hline Education status (levels) & & $0.01(0.02)$ & $0.01(0.02)$ & $0.00(0.02)$ & $0.00(0.02)$ & $0.00(0.02)$ \\
\hline \multicolumn{7}{|l|}{ Socio-economic status } \\
\hline $\begin{array}{l}\text { Owns house in the Netherlands } \\
\text { (1=yes) }\end{array}$ & & & $0.34^{* * *}(0.09)$ & $0.30^{* *}(0.10)$ & $0.12(0.13)$ & $0.30^{* *}(0.10)$ \\
\hline Number of assets in Ghana & & & $0.00(0.02)$ & $-0.01(0.020)$ & $-0.01(0.02)$ & $-0.01(0.02)$ \\
\hline \multicolumn{7}{|l|}{ Social network and migration characteristics } \\
\hline $\begin{array}{l}\text { Number of friends and family in the } \\
\text { Netherlands }\end{array}$ & & & & $0.07(0.04)$ & $0.06(0.04)$ & $0.07(0.04)$ \\
\hline $\begin{array}{l}\text { Documented status in the Netherlands } \\
\text { (1=documented) }\end{array}$ & & & & $0.45^{* *}(0.14)$ & $0.43^{* *}(0.14)$ & $0.11(0.40)$ \\
\hline Number of years in the Netherlands & & & & $0.01(0.01)$ & $0.01(0.01)$ & $0.01(0.01)$ \\
\hline \multicolumn{7}{|l|}{ Interaction effects } \\
\hline $\begin{array}{l}\text { Transnational parent owns house in the } \\
\text { Netherlands }\end{array}$ & & & & & $0.49^{* *}(0.17)$ & \\
\hline Transnational parent is documented & & & & & & $0.37(0.42)$ \\
\hline Constant & $4.28^{* * *}(0.06)$ & $4.11^{* * *}(0.33)$ & $4.09^{* * *}(0.34)$ & $3.71^{* * *}(0.36)$ & $3.85^{* * *}(0.36)$ & $4.05^{* * *}(0.51)$ \\
\hline F-test & $3.41^{+}$ & 1.57 & $3.53^{* * *}$ & $4.66^{* * *}$ & $5.56^{* * *}$ & $4.25^{* * *}$ \\
\hline$N$ & 303 & 303 & 303 & 292 & 292 & 292 \\
\hline$R^{2}$ & 0.01 & 0.03 & 0.06 & 0.12 & 0.14 & 0.13 \\
\hline
\end{tabular}

Source: Data on Transnational Child Raising Arrangements between Ghana and the Netherlands (TCRA), 2011.

Robust standard errors are reported in parentheses. In this and subsequent models, the number of observations is reduced to 292 because of missing values for 11 observations on the number of years in the Netherlands variable.

*** $p<0.001$;

$* * p<0.01$;

${ }^{*} p<0.05$;

${ }^{+} p<0.10$.

variable. The results in this model showed the positive and significant effects of being married or in a relationship and having a higher level of education on satisfaction with life $(p=0.10)$ and better emotional well-being $(p=0.05)$.

In Model 3 (both outcomes), in which socioeconomic status was controlled, the significant effects of being a transnational parent, being married, and having higher educational status disappeared. Additionally, having assets in Ghana significantly affected both outcomes. In Model 4, we additionally controlled for the social network and migration characteristics. The significant variables that were found in Model 3 remained. In addition, documented status was significantly and positively associated with subjective wellbeing. The significance of being a transnational parent disappeared when the documented status variable was included in a separate model. Again, the results suggest that differences in subjective well-being between transnational and non-transnational parents are primarily due to differences in the parents' socio-economic status and documented status.

More specifically, the ownership of a house in the Netherlands significantly increased satisfaction with life $(p=0.01)$ scores by 53 percentage points and reduced the GHQ scores by 1.13 units. Furthermore, an increase in the number of assets owned in Ghana increased satisfaction with life $(p=0.01)$ by 3 percentage points and reduced the GHQ scores $(p=0.05)$ by 11 units. Documented status $(p=0.01)$ significantly improved the two well-being outcomes, increasing the satisfaction scores by 49 percentage points and reducing the GHQ scores by approximately 3 units. A greater number of friends and family members in the Netherlands was significantly $(p=0.10)$ and positively associated with emotional wellbeing. Contrary to the findings of other studies (Dias et al., 2008; Knipscheer et al., 2000), no significant association of duration of stay in the DOI: $10.1002 / p s p$ 
Table 3. Multivariate regressions of self-assessed satisfaction with life: transnational versus non-transnational parents.

\begin{tabular}{|c|c|c|c|c|c|c|}
\hline & Model 1 & Model 2 & Model 3 & Model 4 & Model 5 & Model 6 \\
\hline Transnational parent $(1=$ yes $)$ & $-0.28^{* *}(0.10)$ & $-0.32^{* *}(0.10)$ & $-0.12(0.11)$ & $0.03(0.12)$ & $-0.06(0.14)$ & $-0.18(0.40)$ \\
\hline \multicolumn{7}{|l|}{ Socio-demographic characteristics } \\
\hline Sex $(1=$ male $)$ & & $0.08(0.11)$ & $0.07(0.11)$ & $0.14(0.11)$ & $0.13(0.11)$ & $0.14(0.11)$ \\
\hline Age (years) & & $0.01(0.01)$ & $0.00(0.01)$ & $-0.00(0.01)$ & $-0.00(0.01)$ & $-0.00(0.01)$ \\
\hline $\begin{array}{l}\text { Marital status }(1=\text { married } / \text { in a } \\
\text { relationship) }\end{array}$ & & $0.23^{+}(0.13)$ & $0.16(0.14)$ & $0.14(0.14)$ & $0.14(0.14)$ & $0.14(0.14)$ \\
\hline Education status (levels) & & $0.04^{+}(0.02)$ & $0.03(0.02)$ & $0.02(0.02)$ & $0.02(0.02)$ & $0.02(0.02)$ \\
\hline \multicolumn{7}{|l|}{ Socio-economic status } \\
\hline $\begin{array}{l}\text { Owns house in the Netherlands } \\
\text { (1= yes) }\end{array}$ & & & $0.53^{* * *}(0.10)$ & $0.49^{* *}(0.11)$ & $0.36^{* *}(0.14)$ & $0.49^{* * *}(0.11)$ \\
\hline Number of assets in Ghana & & & $0.04^{* *}(0.01)$ & $0.03 *(0.01)$ & $0.03^{*}(0.01)$ & $0.03^{*}(0.01)$ \\
\hline \multicolumn{7}{|l|}{ Social network and migration characteristics } \\
\hline $\begin{array}{l}\text { Number of friends and family in the } \\
\text { Netherlands }\end{array}$ & & & & $-0.03(0.05)$ & $-0.03(0.05)$ & $-0.03(0.05)$ \\
\hline $\begin{array}{l}\text { Documented status in the } \\
\text { Netherlands ( } 1=\text { documented) }\end{array}$ & & & & $0.48^{* *}(0.15)$ & $0.46^{* *}(0.15)$ & $0.27(0.39)$ \\
\hline Number of years in the Netherlands & & & & $0.01(0.01)$ & $0.01(0.01)$ & $0.01(0.01)$ \\
\hline \multicolumn{7}{|l|}{ Interaction effects } \\
\hline $\begin{array}{l}\text { Transnational parent owns house in the } \\
\text { Netherlands }\end{array}$ & & & & & $0.36^{+}(0.20)$ & \\
\hline Transnational parent is documented & & & & & & $0.23(0.42)$ \\
\hline Constant & $4.10^{* * *}(0.07)$ & $3.28^{* * *}(0.38)$ & $3.36^{* * *}(0.39)$ & $3.08^{* * *}(0.41)$ & $3.18^{* * *}(0.42)$ & $3.29^{* * *}(0.53)$ \\
\hline$F$-test & $8.01^{* * *}$ & $3.51^{* * *}$ & $9.66^{* * *}$ & 7.33 & $7.06^{* * *}$ & $6.65^{* * *}$ \\
\hline$N$ & 303 & 303 & 303 & 292 & 292 & 292 \\
\hline$R^{2}$ & 0.03 & 0.06 & 0.13 & 0.18 & 0.18 & 0.18 \\
\hline
\end{tabular}

Source: Data on Transnational Child Raising Arrangements between Ghana and the Netherlands (TCRA), 2011.

Robust standard errors are reported in parentheses.

${ }_{* * *}^{*} p<0.001$

${ }^{* *} p<0.01$

$* p<0.05 ;$

Netherlands was found for either outcome. The interaction effects reported in Models 5 and 6 showed that transnational parents with better socio-economic status reported better satisfaction with life scores. However, no significant effects were found for emotional well-being.

In summary, negative associations were found between being a transnational parent and the health and subjective well-being outcomes. However, the effects disappeared when controlling for socio-economic status or documented status in the Netherlands. This result suggests that being a transnational parent is not independently associated with low levels of well-being; rather, this association is mediated through low socio-economic status and undocumented status. In fact, as shown in Table 1 , only $15 \%$ of the transnational parents but approximately half of the non-transnational parents owned their house. Nearly all of the nontransnational parents $(98 \%)$ and $68 \%$ of the transnational parents were documented.

\section{Heterogeneity of Transnational Parents}

In a final analysis, only transnational parents were considered to examine the factors that explain heterogeneity in the health and subjective well-being of this group. The estimation results using ordinary least squares regressions are reported in Table 5. The results showed that only socio-economic status in the Netherlands and documented status were significantly and positively associated with all outcomes. More specifically, owning a house in the Netherlands increased the reported scores on health and satisfaction with life by 67 and 84 percentage points, respectively, and reduced the GHQ score by 1.3 units. Furthermore, documented status increased health and satisfaction with life scores by 46 and 51 percentage points, respectively, and reduced the GHQ scores by 3 units.

Of the four transnational parent-specific variables that were added for this analysis, choice to 
Table 4. Multivariate regressions of emotional well-being (GHQ-12): transnational versus non-transnational parents.

\begin{tabular}{|c|c|c|c|c|c|c|}
\hline & Model 1 & Model 2 & Model 3 & Model 4 & Model 5 & Model 6 \\
\hline Transnational parent $(1=$ yes $)$ & $1.17^{* * *}(0.31)$ & $0.98^{* *}(0.33)$ & $0.55(0.35)$ & $-0.45(0.36)$ & $-0.26(0.43)$ & $0.34(2.03)$ \\
\hline \multicolumn{7}{|l|}{ Socio-demographic characteristics } \\
\hline $\operatorname{Sex}(1=$ male $)$ & & $0.42(0.35)$ & $0.46(0.35)$ & $0.06(0.31)$ & $0.07(0.31)$ & $0.06(0.31)$ \\
\hline Age (years) & & $0.03(0.02)$ & $0.04^{+}(0.02)$ & $0.07^{* *}(0.03)$ & $0.07^{* *}(0.03)$ & $0.07^{* *}(0.03)$ \\
\hline $\begin{array}{l}\text { Marital status }(1=\text { married } / \text { in a } \\
\text { relationship) }\end{array}$ & & $-1.13^{*}(0.50)$ & $-0.96^{+}(0.50)$ & $-0.76^{+}(0.44)$ & $-0.76^{+}(0.44)$ & $-0.76^{+}(0.44)$ \\
\hline Education status (levels) & & $-0.15^{*}(0.08)$ & $-0.13^{+}(0.07)$ & $-0.04(0.07)$ & $-0.04(0.07)$ & $-0.04(0.07)$ \\
\hline \multicolumn{7}{|l|}{ Socio-economic status } \\
\hline $\begin{array}{l}\text { Owns house in the Netherlands } \\
(1=\text { yes })\end{array}$ & & & $-1.13^{* * *}(0.29)$ & $-0.89^{* *}(0.31)$ & $-0.64(0.40)$ & $-0.89^{* *}(0.31)$ \\
\hline Number of assets in Ghana & & & $-0.09 *(0.04)$ & $-0.10^{*}(0.04)$ & $-0.10^{*}(0.04)$ & $-0.11^{*}(0.04)$ \\
\hline \multicolumn{7}{|l|}{ Social network and migration characteristics } \\
\hline $\begin{array}{l}\text { Number of friends and family in the } \\
\text { Netherlands }\end{array}$ & & & & $0.30^{+}(0.15)$ & $0.30^{+}(0.15)$ & $0.29^{+}(0.15)$ \\
\hline $\begin{array}{l}\text { Documented status in the } \\
\text { Netherlands }(1=\text { documented })\end{array}$ & & & & $-2.96^{* * *}(0.54)$ & $-2.93^{* * *}(0.53)$ & $-2.19(1.98)$ \\
\hline Number of years in the Netherlands & & & & $-0.04(0.03)$ & $-0.04(0.03)$ & $-0.04(0.03)$ \\
\hline \multicolumn{7}{|l|}{ Interaction effects } \\
\hline $\begin{array}{l}\text { Transnational parent owns house in the } \\
\text { Netherlands }\end{array}$ & & & & & $-0.71(0.55)$ & \\
\hline $\begin{array}{l}\text { Transnational parent is } \\
\text { documented }\end{array}$ & & & & & & $-0.83(2.05)$ \\
\hline Constant & $1.21^{* * *}(0.20)$ & $2.04^{*}(1.20)$ & $1.80(1.23)$ & $2.97^{* *}(1.28)$ & $2.77^{* *}(1.28)$ & $2.21(2.23)$ \\
\hline F-test & $14.00^{* * *}$ & $5.06^{* * *}$ & $6.10^{* * *}$ & $7.63^{* * *}$ & $6.92^{* * *}$ & $6.91^{* * *}$ \\
\hline$N$ & 303 & 303 & 303 & 292 & 292 & 292 \\
\hline$R^{2}$ & 0.04 & 0.10 & 0.13 & 0.28 & 0.28 & 0.28 \\
\hline
\end{tabular}

Source: Data on Transnational Child Raising Arrangements between Ghana and the Netherlands (TCRA), 2011.

Robust standard errors are reported in parentheses.

GHQ-12, General Health Questionnaire-12.

$* * * p 0.001$;

${ }^{* *} p<0.01$;

${ }^{*} p<0.05$

${ }^{+} p<0.10$.

live with children and beginning a reunification procedure were significant for emotional wellbeing only. The results indicated that preference to live with one's child but living separately significantly decreased a parent's emotional well-being by 1.3 units on the GHQ score. On the other hand, beginning a reunification procedure significantly decreased the GHQ score by 0.93 units, suggesting that transnational parents who pursue reunification with their children have better emotional well-being than those who do not.

\section{DISCUSSIONS AND CONCLUSIONS}

Transnational family studies have brought to light the emotional toll international migration takes on families when they are separated by large geographical distances (Zontini, 2004;
Parreñas, 2005; Dreby, 2006; Fresnoza-Flot, 2009; Moran-Taylor, 2008). This literature is primarily based on in-depth small-scale analyses of case studies of migrants primarily from Latin American and Asia. However, by focusing only on parents who are separated from their children, without a comparison group, these studies do not identify the specific conditions that characterise transnational families as compared with non-transnational ones that may lead to worse well-being. Moreover, focusing only on geographic separation fails to capture the potential heterogeneities that exist among transnational migrant parents. To address these gaps in the literature, this study has examined whether and in what ways transnational parenting is associated with the health and subjective well-being of migrant parents by using data collected specifically for this purpose among 303 Ghanaian migrant parents in the Netherlands. 
Table 5. Multivariate regressions of health status and subjective well-being: transnational parents.

\begin{tabular}{|c|c|c|c|}
\hline & $\begin{array}{l}\text { Self-assessed } \\
\text { health }\end{array}$ & $\begin{array}{l}\text { Satisfaction with } \\
\text { life }\end{array}$ & $\begin{array}{l}\text { Emotional well- } \\
\text { being }\end{array}$ \\
\hline \multicolumn{4}{|l|}{ Socio-demographic characteristics } \\
\hline Sex $(1=$ male $)$ & $0.01(0.20)$ & $-0.05(0.23)$ & $0.24(0.62)$ \\
\hline Age (years) & $-0.02(0.01)$ & $-0.02(0.02)$ & $0.12^{* *}(0.05)$ \\
\hline Marital status $(1=$ married $/$ in a relationship $)$ & $-0.02(0.23)$ & $0.17(0.21)$ & $-0.56(0.72)$ \\
\hline Education status (levels) & $0.01(0.03)$ & $0.03(0.04)$ & $0.02(0.12)$ \\
\hline \multicolumn{4}{|l|}{ Socio-economic status } \\
\hline Owns house in the Netherlands (1=yes) & $0.66^{* * *}(0.17)$ & $0.86^{* * *}(0.16)$ & $-1.27^{* *}(0.49)$ \\
\hline Number of assets in Ghana & $-0.02(0.03)$ & $0.01(0.04)$ & $-0.15(0.11)$ \\
\hline \multicolumn{4}{|l|}{ Social network and migration characteristics } \\
\hline Number of friends and family in the Netherlands & $0.11(0.07)$ & $0.01(0.09)$ & $0.05(0.25)$ \\
\hline Documented status in the Netherlands $(1=$ documented $)$ & $0.45^{* * *}(0.16)$ & $0.49^{* * *}(0.18)$ & $-3.06^{* * *}(0.61)$ \\
\hline Number of years in the Netherlands & $0.03(0.02)$ & $0.01(0.02)$ & $-0.07(0.05)$ \\
\hline \multicolumn{4}{|l|}{ Other characteristics } \\
\hline Caregiver is the other biological parent ( $1=$ yes $)$ & $0.02(0.17)$ & $0.16(0.20)$ & $-0.40(0.54)$ \\
\hline Number of children below 11 years & $0.14(0.10)$ & $-0.05(0.13)$ & $-0.38(0.39)$ \\
\hline Prefers to live with child $(1=$ yes $)$ & $-0.01(0.19)$ & $-0.20(0.19)$ & $1.27^{* *}(0.54)$ \\
\hline $\begin{array}{l}\text { Ever started a procedure to bring child to the Netherlands } \\
\text { (1=yes) }\end{array}$ & $0.24(0.18)$ & $0.04(0.15)$ & $-0.96^{* *}(0.40)$ \\
\hline Constant & $3.71^{* * *}(0.66)$ & $3.62^{* * *}(0.71)$ & $0.46^{* * *}(2.38)$ \\
\hline F-test & $4.55^{* * *}$ & $4.77^{* * *}$ & $5.35^{* * *}$ \\
\hline$R^{2}$ & 0.22 & 0.24 & 0.35 \\
\hline
\end{tabular}

Source: Data on Transnational Child Raising Arrangements between Ghana and the Netherlands (TCRA), 2011.

$N=140$. Robust standard errors are reported in parentheses.

$* * *<0.01$;

$* * p<0.05$

${ }^{*} p<0.1$.

Our findings make several contributions to the literature. First, the use of a control group of parents who live with all of their children in the receiving country allowed us to see, first descriptively, that transnational parents indeed are worse off in their health and well-being compared with parents who live with their children, a finding in line with the qualitative transnational family literature (Parrenãs, 2005; Dreby, 2007; Bernhard et al., 2008). However, we show that this negative wellbeing experienced by transnational parents is more than a separation story, as is currently emphasised in the literature. Rather, by controlling for different migrant characteristics, we find that poorer wellbeing is associated with low socio-economic and undocumented statuses, which happen to be the most common attributes of Ghanaian transnational parents in our data.

These findings shift the focus of transnational parenting from being a separation issue to it being a migration project - a project typically initiated to economically provide for children and families in the home country. The success of this project is conditional on socio-economic and documented statuses. The ability to send remittances to the country of origin is a means of fulfilling social obligations and parental duties (McKay, 2007; Wong, 2014). Migrants, as interviews with Ghanaian fathers in the Netherlands showed, can feel satisfied with living transnationally if they are able to materially provide for their children and to pay for the fees to send them to high-quality schools (Poeze \& Mazzucato, 2012). This is because sufficient income facilitates the transfer of remittances, and the intensity and frequency of communication through telephone. Failure to fulfil financial obligations can result in frustration and the subsequent withdrawal of parents from contacting their family in the country of origin (Dreby, 2006). Socio-economic status is also vital in facilitating return visits, where sufficient income and stable contracts allow migrants to afford trips home and to take time off work (Parreñas, 2001). Undocumented status, besides determining migrants' labour market opportunities, plays a fundamental role in lengthening the time of 
separation between migrant parents and their children (Mazzucato \& Schans, 2011; Fresnoza-Flot, 2009). Ghanaian documented transnational parents in our data send more remittances, visit their children more often, and earn more than the undocumented transnational parents.

Second, our study makes a distinction between transnational parents who are so by choice and those who are coerced by circumstances to be in a transnational family arrangement. There is little focus given in the literature on how choice factors in a transnational parenting arrangement. We show that parents who prefer their children to live in Ghana are emotionally well-off compared with parents who prefer to have their children live with them in the Netherlands. Because of data limitations, we cannot explain how parents arrive at these choices, yet our findings point to the importance of recognising parents' agency in engaging in transnational parenting and the implication of this on their emotional well-being. This is an important addition to the transnational family literature because it shows that transnational family life can be a preferred option, and when it is, the consequences on parental well-being are not the same as when it is a coerced option.

We hypothesise that a reason why we do not find poorer well-being among transnational parents and why some parents may choose to live in a transnational family arrangement is the normative context in Ghana, highlighting the importance of family norms in origin countries. Norms of child fostering and social parenthood guide the way that 'good parenting' is perceived (Whitehouse, 2009; Mazzucato \& Schans, 2011). To raise a child by people other than the biological parents is considered a way to provide future opportunities for one's child, to establish kinship linkages with other members of society, and to avoid spoiling a child (Goody, 1982). Nearly $30 \%$ of our respondents were fostered when they were young. Parents who have been socialised in a system in which it is common to have others raise one's children may not experience the feelings of guilt or of being a 'bad' parent. Such systems are not unique to the Ghanaian context as similar norms are also documented among Caribbean transnational families where care for children through kinship networks is historically commonplace (Olwig, 1999; Reynolds \& Zontini, 2006; Reynolds, 2005). The presence of such norms among Caribbean families helps to facilitate parental migration, especially that of women, in the context of a care chain that enables women to improve their socio-economic position as well as that of those they leave behind (Olwig, 1999).

Not only are sending country contexts of importance but so are receiving country contexts. Our findings on the importance of socioeconomic and documented statuses for the wellbeing of migrant parents in the receiving country have implications with regard to migration policies and policies that regulate the recognition of qualifications of foreign diplomas, which are quite restrictive in the Netherlands (Caarls et al., 2013; Mazzucato, 2008). These policies have repercussions on the well-being of migrant parents through the impediments that they create for parents to provide for their children materially and to maintain an active relationship with them.

The current study has some limitations. It used a non-random sampling strategy because of a lack of baseline data on Ghanaians in the Netherlands. In addition, because of the cross-sectional nature of the data, it was not possible to observe how well-being progresses over time. Despite these limitations, this study contributes to the literature on transnational migrant families and migrant well-being by calling into question that geographic proximity is a prerequisite for healthy family functioning. This shows that families create a transnational space (through their communication, visits, and remittance-sending practices) that allows families to operate across large distances without necessarily impinging on their well-being. Yet it also shows that family functioning is situated in particular places: Ghanaian normative family context helps to explain why parents may not suffer if they are able to cater for their children at a distance, and Dutch migration and labour policies can help to explain why some parents in transnational families have poorer emotional well-being.

\section{ACKNOWLEDGEMENTS}

The research presented in this article was conducted as part of the Transnational ChildRaising Arrangements between Ghana and the Netherlands (TCRA) project funded by the Netherlands Organization for Scientific Research, WOTRO Science for Development Division (WOTRO/NWO grant number W01.65.316).

Popul. Space Place 2017; 23: e2006 DOI: $10.1002 / p s p$ 


\section{REFERENCES}

Bennett R, Hosegood V, Newell ML, McGrath N. 2014. Understanding family migration in rural South Africa: exploring children's inclusion in the destination households of migrant parents. Population Space and Place 21: 310-21.

Berk ML, Schur CL, Chavez LR, Frankel M. 2000. Healthcare use among undocumented Latino immigrants. Health Affairs 19: 51-64.

Bernhard JK, Landolt P, Goldring L. 2008. Transnationalizing families: Canadian immigration policy and the spatial fragmentation of care-giving among Latin American newcomers. International Migration 47: 3-31.

Bledsoe C, Sow P. 2011. Back to Africa: second chances for the children of West African immigrants. Journal of Marriage and Family 73: 747-762.

Bledsoe C, Isingo-Abanike U. 1989. Strategies of childfosterage among Mende grannies in Sierra Leone. In Reproduction and Social Organization in Sub-Saharan Africa, Lesthaeghe R. (ed). University of California Press: Berkeley; 442-474.

Caarls K, Schans D, Mazzucato V, Quartey P, Addoquaye TC. 2013. Transnational Families between Ghana, the Netherlands and the U.K. MAFE Working Paper no. 32. Paris: INED.

Cavazos-Rehg PA, Zayas LH, Spitznagel EL. 2007. Legal status, emotional well-being and subjective health status of Latino immigrants. Journal of the National Medical Association 9910: 1126-131.

Central Bureau of Statistics. 2014. 2014, http:/ /statline.cbs. $\mathrm{nl} /$ StatWeb/publication/ ?DM=SLNL\&PA=37325\& $\mathrm{D} 1=\mathrm{a} \& \mathrm{D} 2=\mathrm{a} \& \mathrm{D} 3=0 \& \mathrm{D} 4=0 \& \mathrm{D} 5=76 \& \mathrm{D} 6=9-17 \&$ $\mathrm{VW}=\mathrm{T}$. [accessed on 3 February 3 2014].

Central Bureau of Statistics. 2015. http:/ / www.cbs.nl/ en-GB/menu/themas/bevolking/publicaties/artikelen/ archief/2015/population-growth-in-2014-nearly-73-thousand-more-immigrants-and-more-babieshtm.htm. [accessed 2 June 2015].

Coe C. 2008. The structuring of feelings among Ghanaian transnational families. City and Society 20: 222-250.

Chen J, Wilkens R, Ng E. 1996. Life expectancy of Canada's immigrants from 1986 to 1991 . Health Reports 8: 29-38.

Dias S, Severo M, Barros H. 2008. Determinants of health care utilization by immigrants in Portugal. BMC Health Services Research 8: 207.

Diener E. 1994. Assessing subjective well-being: progress and opportunities. Social Indicators Research 31: 103-157.

Dreby J. 2006. Honor and virtue - Mexican parenting in the transnational context. Gender and Society 20: 32-59.

Dreby J. 2007. Children and power in Mexican transnational families. Journal of Marriage and Family 69: 1050-1064.
Donath S. 2001. The validity of the 12-item General Health Questionnaire in Australia: a comparison between three scoring methods. Australia and New Zealand Journal of Psychiatry 35: 231-235.

Dunn J, Dyck I. 2000. Social determinants of health in Canada's immigrant population: results from the national population health survey. Social Science and Medicine 51: 1573-1593.

Fan F, Su L, Gill MK, Birmaher B. 2012. Emotional and behavioral problems of Chinese left-behind children: a preliminary study. Social Psychiatry and Psychiatric Epidemiology 45: 655-64.

Fresnoza-Flot A. 2009. Migration status and transnational mothering: the case of Filipino migrants in France. Global Networks 9: 252-270.

Frisbie WP, Youngtae C, Hummer RA. 2001. Immigration and the health of Asian and Pacific Islander adults in the United States. American Journal of Epidemiology 153: 372-380.

Ghana Statistical Service. 2010. Population and Housing Census. http://www.statsghana.gov.gh/docfiles/publications/2010_PHC_demographic_social_economic_ housing_characteristics.pdf. [Viewed 26 May 2015].

Giannelli G, Mangiavacchi L. 2010. Children's schooling and parental migration: empirical evidence on the 'leftbehind generation' in Albania. Labour 24: 76-92.

Goody J. 1982. Parenthood and Asocial Reproduction: Fostering and Occupational Roles in West-Africa. Cambridge University Press: Cambridge.

Griffin J, Soskolne V. 2003. Psychological distress among Thai migrant workers in Israel. Social Science and Medicine 57: 769-774.

Grillo R, Mazzucato V. 2008. Africa, Europe: A double engagement. Journal of ethnic and migration studies 34: 175-198.

Goldberg DP. 1978. Manual of the General Health Questionnaire. NFER Publishing: Windsor.

Hao L, Johnson R. 2000. Economic, cultural, and social origins of emotional well-being: comparisons of immigrants and natives at midlife. Research on Aging 22: 599-629.

Horton S. 2009. A mother's heart is weighed down with stones: a phenomenological approach to the experience of transnational motherhood. Culture, Medicine and Psychiatry 3: 21-40.

Idler EL, Benyamini Y. 1997. Self-rated health and mortality: a review of twenty-seven community studies. Journal of Health and Social Behavior 38: 21-37.

Idler E, Kasl S. 1995. Self-ratings of health: do they also predict change in functional ability. Journal of Gerontology: Social Sciences 50B: S344-S353.

Jackson C. 2007. The General Health Questionnaire. Occupational Medicine 57: 57-79.

Jasinskaja-Lahti IL, Karmela J, Reuter MA. 2006. Perceived discrimination, social support networks, and psychological well-being among three immigrant groups. Journal of Cross Cultural Psychology 37: 293-311. 
Knipscheer JW, De Jong EE, Kleber RJ, Lamptey E. 2000. Ghanaian migrants in the Netherlands: general health, acculturative stress and utilization of mental health care. Journal of Community Psychology 28: 459-476.

Lebrun LA. 2008. Effects of length of stay and language proficiency on health care experiences among immigrants in Canada and the United States. Social Science and Medicine 74: 1062-1072.

Leu J, Yen IH, Stuart A, Gansky SA, Walton E, Nancy E, Adler NE, Takeuchi DT. 2008. The association between subjective social status and mental health among Asian immigrants: investigating the influence of age at immigration. Social Science and Medicine 66: 1152-1164.

McKenzie D, Rapoport H. 2011. Can migration reduce educational attainment? Evidence from Mexico. Journal of Population Economics 24: 1331-58.

Manuh T. 1999. 'This place is not Ghana': gender and rights discourse among Ghanaian men and women in Toronto. Ghana Studies 2: 77-95.

Mazzucato V. 2008. The double engagement: transnationalism and integration - Ghanaian migrants' lives between Ghana and the Netherlands. Journal of Ethnic and Migration Studies 34: 199-216.

Mazzucato V, Schans D. 2011. Transnational families and the well-being of children: conceptual and methodological challenges. Journal of Marriage and Family 73: 704-712.

Mazzucato V. 2012. Transnational families. In The Encyclopedia of Global Human Migration, Ness I. (ed). Blackwell Publishing: Oxford.

Mazzucato V. Cebotari V. Veale A. White A. Grassi M. Vivet J. 2014. International parental migration and the psychological well-being of children in Ghana, Nigeria, and Angola. Social Science and Medicine 132: 215-224.

McKay D. 2007. Sending dollars shows feelingemotions and economies in Filipino migration. Mobilities 2: 175-194.

Montazeri A, Harirchi AM, Shariati M, Garmaroudi G, Ebadi M, Fateh A. 2003. The 12-item General Health Questionnaire (GHQ-12): translation and validation study of the Iranian version. Health and Quality of Life Outcomes 1: 66.

Moran-Taylor MJ. 2008. When mothers and fathers migrate North: caretakers, children and child rearing in Guatemala. Latin American Perspectives 35: 79-95.

Nobles J. 2011. Parenting from abroad: migration, nonresident father involvement, and children's education in Mexico. Journal of Marriage and Family 73: 729-746.

Noh S, Avison WR. 1996. Asian immigrants and the stress process: a study of Koreans in Canada. Journal of Health and Social Behavior 37: 192-206.

Olwig KF. 1999. Narratives of the children left behind: home and identity in globalised Caribbean families. Journal of Ethnic and Migration Studies 25: 267-284.
Oppedal B, Roysamb E, Lackland SD. 2004. The effect of acculturation and social support on change in mental health among young immigrants. International Journal of Behavioral Development 28: 481-494.

Oppong C. 1973. Growing Up in Dagbon. Ghana Publishing Corporation: Accra.

Parreñas RS. 2001. Mothering from a distance: emotions, gender, and inter-generational relationships in Filipino transnational families. Feminist Studies 27: 361-390.

Parreñas RS. 2005. Long distance intimacy: class, gender and intergenerational relations between mothers and children in Filipino transnational families. Global Networks 5: 317-366.

Peil M. 1995. Ghanaians abroad. African Affairs 94: 345-67.

Poeze M, Mazzucato V. 2012. Committed Fathers from Afar: Gender, Class and Legal Status in Male Migrant's Transnational Care Practices between Amsterdam and Ghana, IMISCOE conference paper. University of Amsterdam.

Quartey P. 2009. Migration in Ghana. Country Profile 2009. International Organization for Migration: Geneva.

Reynolds T. 2005. Caribbean Mothers: Identity and Experience in the UK. Tufnell Press: London.

Reynolds T, Zontini E. 2006. A Comparative Study of Care and Provision across Caribbean and Italian Transnational Families. London South Bank University: London.

Sharareh A, Carina B, Sarah W. 2007. The health of female Iranian immigrants in Sweden: a qualitative six-year follow-up study. Health Care for Women International 28: 339-359.

Schans D, Mazzucato V, Schoumaker B, Flahaux MF. 2013. Changing patterns of Ghanaian migration. MAFE Working Paper No. 20, pp. 22. INED, France. Schmalzbauer L. 2004. Searching for wages and mothering from afar: the case of Honduran transnational families. Journal of Marriage and Family 66: 1317-1331.

Schmitz N, Kruse J, Tress W. 1999. Psychometric properties of the General Health Questionnaire (GHQ-12) in a German primary care. Acta Psychiatrica Scandanavica 100: 462-468.

Tizard B. 1991. Employed mothers and the care of young children, In Motherhood: Meaning, Practices and Ideologies, Phoenix A. Woollet A, Lloyd E. (eds). Sage: London; 178-194.

Twum-Baah KA. 2005. Volume and characteristics of international Ghanaian migration. In At Home in the World? International Migration and Development in Contemporary Ghana and West Africa, Manuh T. (ed). Sub-Saharan Africa Press: Accra.

Van Huis M, Nicolaas H, Croes M. 2004. Migration of the Four Largest Cities in the Netherlands. Statistics Netherlands: Department of Population, the Netherlands.

Van Walsum S. 2003. Comment on the Sen case. How wide is the margin of appreciation regarding the 
admission of children for purposes of family reunification. European Journal of Migration and Law 4: 511-520.

Viruell-Fuentes EA. 2006. My heart is always there: the transnational practices of first generation Mexican immigrant and second-generation Mexican American women. Identities 13: 335-362.

Whitehouse B. 2009. Transnational childrearing and the preservation of transnational identity in Brazzaville, Congo. Global Networks 9: 82-99.

Wong M. 2014. Navigating return: the gendered geographies of skilled return migration to Ghana. Global Networks. 14: 438-457.
World Bank. 2015. http://data.worldbank.org/country/ghana. [accessed 15 July 2015].

Zhang W, McCubbin H, McCubbin L, Chen Q, Foley S, Strom I, Kehl L. 2010. Education and self-rated health: an individual and neighborhood level analysis of Asian Americans, Hawaiians, and Caucasians in Hawaii. Social Science and Medicine 70: 561-569.

Zontini E. 2004. Immigrant women in Barcelona: coping with the consequences of transnational lives. Journal of Ethnic and Migration Studies 30: 1113-1144. 